\title{
Physical condition of female students with different level of body mass deficiency
}

\author{
Kolokoltsev M.M. ${ }^{\text {ABCDE }}$, Iermakov S.S. ${ }^{2 A B C D E}$, Jagiello M. ${ }^{3 A B C D E}$ \\ ${ }^{1}$ Department of the Physical Culture, Irkutsk National Research Technical University, Russia \\ ${ }^{2}$ Department of Tourism and Recreation, Gdansk University of Physical Education and Sport, Poland \\ ${ }^{3}$ Department of Theory of Sport and Human Motority, Gdansk University of Physical Education and Sport, Poland
}

Authors' Contribution: A - Study design; B - Data collection; C - Statistical analysis; D - Manuscript Preparation; E - Funds Collection.

\begin{abstract}
Purpose: $\quad$ to study the features of morphofunctional and motor characteristics of female students with body mass deficiency and with normal body mass.

Material: $\quad$ it was examined 17-21-year-old female students $(n=1937)$. All students were in the main medical group according to the health condition and attended classes on discipline Physical culture. It was carried out the anthropometrical and physiometric examination of female students.

Results: It was determined the low integrated criterion of physical fitness of female students with body mass deficiency. It was defined the dependence between the decrease in level of physical fitness and decrease in body mass of female students. It was determined reliable differences between the morphofunctional parameters and results of motor tests of female students with different body mass.

Conclusions: The obtained data allow to correct educational process on physical training of students using integrative pedagogical methods and methods of training.

Keywords: physical training, female students, body mass, morphofunctional, anthropometrical.
\end{abstract}

\section{Introduction}

The body mass of the person is the integrated criterion of levels of metabolic, energy, hormonal, and other processes in a human body [1, 2] and now it is considered by many researchers as one of the key parameters of physical development of the person [3, 4].

Recent researches devoted to the physical development of the students witness about the increase in a number of students with body mass deficiency or excess body mass. The number of students of full-time study with a deviation of body mass reaches 30-40\% [5]. There are a few scientific works devoted to problems of students' body mass deficiency in comparison with works concerning problems of excess body mass [6].

More than 30\% students of Volga Technical Institute have problems with body mass: increase and decrease of the norm. $17,7 \%$ females and $12,5 \%$ males of this institute have a body mass deficiency [7]. According to the authors, it indicates the serious disorder of constructive metabolism processes in the young organism. About $18 \%$ students of Moscow Universities have a body mass deficiency. Then females have the body mass deficiency in twice more often than males [8]. Among students of Yaroslavl Medical University, females have body mass deficiency more often than males (25\% and $17 \%$ respectively) [9]. It is defined that the number of students with body mass deficiency doubles from $15,5 \%$ in 18 years up to $30,6 \%$ in 23 years [10]. There is a research proved that $63,5 \%$ female students of Far Eastern Federal University with body mass deficiency have decrease in working capacity [11].

The considerable deviation of body mass from norm

(C) Kolokoltsev M.M., lermakov S.S., Jagiello M., 2018 doi:10.15561/20755279.2018.0202 influences on physical and mental activities, the somatic health of the person. Also, it affects negatively on professional activity [8], reproductive system of females $[12,13]$, complicates pregnancy and childbirth $[14,15]$.

The modern process of students' studying becomes more computerized [16] and inactive [17, 18]. It is determined the decrease in the motivation of students to physical culture training [19]. A lot of researchers consider the following reasons of students' body mass deviation from the norm: hypodynamia [20, 21], a disorder of nutritional status [22], hormonal changes in the organism [23], the influence of psychogenic factors [24]. The increase of intellectual and psychoemotional loads, noncompliance with a base of a healthy lifestyle by students $[2,30]$, interest in computer games and Internet influence negatively on physical [25, 26], mental [27] and somatic $[28,29]$ health of the youth.

The body mass of the person responds to the volume, intensity, and regularity of physical culture and sports training [31, 32]. The component structure of a body is the level and harmony of person's physical development. The component structure of a body is the criterion of health condition and physical activity of the person [33, 34].

It is determined that the physical fitness and physical development of students with body mass deficiency are closely connected with a muscular component of body structure on the basis of the analysis of correlation interrelations [35]. Therefore, such students demonstrate low results in tests of hands' muscle strength [36, 37] and the general endurance [35] at physical culture training. There are data that students with body mass deficiency have hands' muscles strength decrease almost twice [11]. It is determined the dependence between the content of muscle mass in the component structure of female 
students' body and the number of classes on discipline "Physical culture" [38].

Studying of questions concerning level's interrelation of students' physical development with physical activity, the comparative analysis of morphofunctional characteristics and physical fitness of female students with different body mass is relevant.

Hypothesis. Authors presuppose that the received results of a research can be used during creation of individual and motivated motor programs for correction of the physical condition of female students with body mass deficiency.

The purpose of the work is to study features of the morphofunctional and motor characteristics of the organism of female students' with body mass deficiency in comparison with physical conditions of females with normal body mass.

\section{Material and methods.}

Participants. it was examined female students of junior courses ( $\mathrm{n}=1937$, 17-21-year-old) of Irkutsk National Research Technical University. All students were in the main medical group according to the health condition and attended classes on discipline Physical culture. 2 times a week. The performed work doesn't prejudice the rights and doesn't endanger the wellbeing of female students according to ethical standards [39].

Organization of a research. The anthropometrical and physiometric examination of female students was conducted using standard techniques [40]. The females were divided into three groups: with the normal body mass "N"; with body mass deficiency " $D$ "; excess body mass "E". The sample of examined females was divided into 5 sigma classes (gradations) according to the body mass parameter value: $\mathrm{M} \pm 0,67 \sigma-$ is "average" value of body mass parameter for sample. If the value of parameter was within the range from $\mathrm{M} \pm 0,67 \sigma$ to $\mathrm{M} \pm 1,34 \sigma$, the body mass value was estimated as "above average" or "below average". If the value of an parameter was beyond of $\mathrm{M} \pm 1,34 \sigma$, the gradation was estimated as "high" or "low".

For the characteristic of morphofunctional parameters was measured:

- body length, cm;

- body mass, kg;

- chest circumference (CC), cm;

- circumference of body parts, cm;

- skinfold thickness (caliperometry), mm;

- heart beat rate before load (HBR), beats $10 \mathrm{sec}$;

- heart beat rate after 20 squats in $30 \mathrm{sec}$ (HBR), beats/10 sec;

- heart beat rate recovery time after 20 squats, min;

- $\quad$ systolic arterial blood pressure (ABPS), mm Hg;

- diastolic arterial blood pressure (ABPD), mm Hg.;

- vital lung capacity (VLC), l;

- dynamometry of both hands, kg.

It was estimated: mass-growth Quetelet index II [41] (BMI= body mass index / body length ${ }^{2}, \mathrm{~kg} / \mathrm{m}^{2}$ ); Robinson
Index [42] (IRob = HBRxABPS: 100, c.u.); vital index (VI = VLC/body mass [43], ml/kg); strength index (SI $=$ hand muscle strength /body mass x100\%) [44]. The average value of absolute and percentage content of fatty and muscular tissue in body was estimated according Ya. Mateyko formulas [45]. The BMI was measured according to the WHO classification (1999) [46]: body mass deficiency, when BMI is less than $18,5 \mathrm{~kg} / \mathrm{m} 2$; norm, when BMI is within $18,5-24,99 \mathrm{~kg} / \mathrm{m} 2$; at the excess body mass $B M I=25-30 \mathrm{~kg} / \mathrm{m} 2$; BMI is higher than $30 \mathrm{~kg} / \mathrm{m} 2-$ obesity of different degrees.

The motor qualities of female students were measured using the range of tests. It was used the following tests: $20 \mathrm{~m}$ run (sec); 10x5 m shuttle run (sec); 5 min run (m); hung (sec); sit-up (times); trunk flexion $(\mathrm{cm})$; standing long jump, trunk flexion (cm) $[47,48]$.

Statistical analysis. It was used programs "Microsoft Excel”, "StatSoft Statistica 6.1" and the author's complex "Analysis of Physical Health Data of Population” (state registration of the program ECM №2010612275, from $3 / 26 / 2010$ ). It was defined the arithmetic average value of parameters $(\mathrm{M})$, mean square deviation $(\sigma)$ and standard error (SE). The reliability of distinctions of average values of independent samples was estimated by parametrical methods by means of Student t-test. Statistically significant were considered differences between values of parameters at level $\mathrm{p}<0,05$.

\section{Results.}

The examined female students ( $\mathrm{n}=1937)$ were divided into three groups according to the body mass parameter value. Group "N" ( $n=1010$, females with normal body mass $-52,14 \%$ ) in which the value of parameter is within interval of sigma deviation $M= \pm 0,67 \sigma$ (tab. 1); group " $D$ " $(\mathrm{n}=526$, females with body mass deficiency $-27,15 \%)$; group " $E$ " (n=401, females with excess body mass $20,7 \%$ ). Females of group " $E$ " didn't participate in further work.

It was determined the decrease of BMI parameter value by $14,9 \%$ in females of group " $\mathrm{D}$ " in comparison with females of the group " $N$ ".

Females of groups " $\mathrm{N}$ " have better somatometrics and physiometrics parameters, than all females with body mass deficiency $(p<0,05)$. Females of groups " $D$ " with gradation "below average" have lower value of parameters of flexibility and trunk muscle strength tests (tab. 2). In this group muscle strength of shoulder girdle were higher, than in females of groups " $N$ " $(p<0,05)$.

Females of group "D" with gradation "low" of body mass have the lowest parameters in four of seven physical fitness tests (shuttle run, $20 \mathrm{~m}$ run, $5 \mathrm{~min}$ run, sit-up). Strength parameter in the test "hung" was higher, than in females of groups "N".

Results of research of body structure component (fig. 1) shown the difference of quantitative content of muscular (MM) and fatty (FM) mass between females with body mass deficiency and female students with normal body mass $(\mathrm{p}<0,05)$.

In body component structure of females of group " $D$ ” 
Table 1. Morphofunctional characteristics $(\mathrm{M} \pm \mathrm{m})$ of females with a different gradation of body mass parameter value

\begin{tabular}{|c|c|c|c|}
\hline \multirow{2}{*}{ Parameters } & Normal body mass & \multicolumn{2}{|c|}{ Body mass deficiency (group «D») } \\
\hline & $\begin{array}{l}\text { Average } \\
(M= \pm 0,67 \sigma) \\
n=1010\end{array}$ & $\begin{array}{l}\text { Below average } \\
\text { (from } M=-0,67 \sigma \text { to } \\
M=-1,34 \sigma \text { ), } n=412\end{array}$ & $\begin{array}{l}\text { Low } \\
\text { (less } \\
M=-1,34 \sigma), n=114\end{array}$ \\
\hline \multicolumn{4}{|l|}{ Somatometrics } \\
\hline body length, cm; & $165,2 \pm 0,15$ & $163,0 \pm 0,21 *$ & $160,2 \pm 0,49 * \#$ \\
\hline body mass, kg; & $55,5 \pm 0,08$ & $48,7 \pm 0,05^{*}$ & $44,7 \pm 0,11^{* \#}$ \\
\hline chest circumference, $\mathrm{cm}$ & $86,7 \pm 0,11$ & $84,2 \pm 0,18^{*}$ & $81,8 \pm 0,29 * \#$ \\
\hline \multicolumn{4}{|l|}{ Physiometrics } \\
\hline VLC, ml & $2700,0 \pm 1,10$ & $2650,0 \pm 1,0 *$ & $2530,0 \pm 4,0 * \#$ \\
\hline dynamometry of right hand, $\mathrm{kg}$ & $24,4 \pm 0,17$ & $23,9 \pm 0,23$ & $22,2 \pm 0,49 * \#$ \\
\hline dynamometry of left hand, kg & $23,4 \pm 0,16$ & $22,7 \pm 0,22 *$ & $21,6 \pm 0,44^{* \#}$ \\
\hline HBR at rest, beats/10 sec & $11,2 \pm 0,02$ & $11,8 \pm 0,04 *$ & $12,9 \pm 0,07^{* \#}$ \\
\hline $\begin{array}{l}\text { HBR after } 20 \text { squats in } 30 \mathrm{sec} \text {, beats/10 } \\
\text { sec }\end{array}$ & $20,9 \pm 0,08$ & $21,1 \pm 0,12$ & $20,2 \pm 0,28 \#$ \\
\hline $\begin{array}{l}\text { HBR recovery time after } 20 \text { squats in } 30 \\
\text { sec, } \min \end{array}$ & $1,43 \pm 0,01$ & $1,46 \pm 0,03$ & $1,59 \pm 0,06^{* \#}$ \\
\hline ABPS, $\mathrm{mm} \mathrm{Hg}$. & $104,4 \pm 0,28$ & $105,3 \pm 0,46$ & $105,5 \pm 0,81$ \\
\hline ABPD, $\mathrm{mm} \mathrm{Hg}$. & $68,8 \pm 0,17$ & $69,1 \pm 0,32$ & $69,0 \pm 0,49$ \\
\hline \multicolumn{4}{|l|}{ Indexes } \\
\hline Body mass index, $\mathrm{kg} / \mathrm{m}^{2}$ & $20,2 \pm 0,07$ & $18,07 \pm 0,09 *$ & $17,19 \pm 0,12^{* \#}$ \\
\hline Robinson Index, c.u. & $70,2 \pm 0,22$ & $74,5 \pm 0,39 *$ & $81,6 \pm 0,52 * \#$ \\
\hline Vital index, ml/kg & $48,6 \pm 0,12$ & $54,4 \pm 0,27^{*}$ & $56,5 \pm 0,44^{* \#}$ \\
\hline Strength index of right hand, \% & $43,9 \pm 0,11$ & $49,1 \pm 0,22 *$ & $49,6 \pm 0,38 *$ \\
\hline Strength index of left hand, \% & $42,1 \pm 0,10$ & $46,6 \pm 0,20 *$ & $48,3 \pm 0,35^{* \#}$ \\
\hline
\end{tabular}

Note: * - reliable differences between parameters of " $N$ " and “ $D$ " groups $(P<0,05)$

\#- reliable differences of parameters in group “ $D$ ” $(P<0,05)$

Table 2. Results of motor tests $(M \pm m)$ of females with different gradation of body mass parameter value

\begin{tabular}{|c|c|c|c|}
\hline \multirow[b]{2}{*}{ Tests } & $\begin{array}{l}\text { Normal body mass } \\
\text { (group «N») }\end{array}$ & \multicolumn{2}{|l|}{$\begin{array}{l}\text { Body mass deficiency } \\
\text { (group «D») }\end{array}$} \\
\hline & $\begin{array}{l}\text { Gradation } \\
\text { Average } \\
(M= \pm 0,67 \sigma), \\
n=1010\end{array}$ & $\begin{array}{l}\text { Below average } \\
\text { (from } M=-0,67 \sigma \text { to } \\
M=-1,34 \sigma), n=412\end{array}$ & $\begin{array}{l}\text { Low (less } \\
M=-1,34 \sigma), n=114\end{array}$ \\
\hline $20 \mathrm{~m}$ run, sec & $3,93 \pm 0,05$ & $3,95 \pm 0,07$ & $4,37 \pm 0,20 * \#$ \\
\hline $10 \times 5 \mathrm{~m}$ shuttle run, sec & $21,10 \pm 0,06$ & $21,16 \pm 0,09$ & $22,64 \pm 0,17^{*} \#$ \\
\hline 5 min run, $m$ & $909,7 \pm 6,06$ & $902,2 \pm 7,82$ & $834,6 \pm 23,1^{*} \#$ \\
\hline hung, sec & $9,93 \pm 0,17$ & $11,0 \pm 0,27 *$ & $11,6 \pm 0,59 *$ \\
\hline sit-up (times) & $23,6 \pm 0,22$ & $22,2 \pm 0,38 *$ & $21,1 \pm 0,66^{*}$ \\
\hline trunk flexions, cm & $15,8 \pm 0,22$ & $14,05 \pm 0,34 *$ & $14,4 \pm 0,78$ \\
\hline standing long jump, cm & $153,6 \pm 0,54$ & $152,2 \pm 0,87$ & $151,4 \pm 1,39$ \\
\hline $\begin{array}{l}\text { integral criterion of physical condition, } \\
\text { points }\end{array}$ & $3,4 \pm 0,01$ & $2,97 \pm 0,01 *$ & $2,68 \pm 0,29 *$ \\
\hline
\end{tabular}

Note: * - reliable differences between parameters of " $N$ " and " $D$ " groups $(P<0,05)$

\# - reliable differences of parameters in group " $D$ ” $(P<0,05)$ 
with gradation of body mass "below average" content of muscular (in 9,3\%) and fatty (in 12,3\%) mass is less, than in females of group " $\mathrm{N}$ " with gradation "average". Females of groups " $D$ " with gradation of body mass "low" have less content of muscular (in 14,8\%) and fatty (in $27,2 \%$ ) mass in body component structure, than in female students of group "N" with norm body mass.

\section{Discussion}

Body mass characterizes level of metabolic, energy, plastic and other processes in a human body [1, 49]. According to the WHO classification, the body mass index parameter value $<18,5 \mathrm{~kg} / \mathrm{m}^{2}$ is considered as chronic energy insufficiency or body mass deficiency [46]. Study of the body mass deficiency distribution among youth, especially females as future mothers, is relevant $[12,50]$. According to our data, approximately $27,15 \%$ of females students of Baikal Technical University have body mass deficiency. This parameter is within the sigma deviation from $\mathrm{M}=-0,67 \sigma$ to $\mathrm{M}=-1,34 \sigma$ and below that will comport with results of other researchers in various regions of Russia $[9,10]$.

The analysis of our results showed the difference between somatometric and physiometric parameters of females with normal body mass and body mass deficiency. Females of groups "N" have better somatometric parameters (length and body mass, CC) and physiometric parameters (VLC, dynamometry of hands' muscle strength, HBR at rest and HBR recovery time after 20 squats, Robinson's Index), than all females of groups " $D$ ” $(p<0,05)$. Among females of group " $D$ " higher results of somatometric and physiometric parameters have females with gradation "below average", than females with gradation "low" ( $p<0,05$; except the characteristic of HBR after 20 squats in $30 \mathrm{sec}$ ). Results of our researches are confirmed by scientific works concerning the interrelation between body mass deficiency, a disharmony of physical development and low physical working capacity among students of Far Eastern Federal University [11] and Ural Federal District of Russia [51].

According our data all females with body mass deficiency have reliable low parameter of cardiovascular system condition (HBR at rest and HBR recovery time after 20 squats), than females with normal body mass $(p<0,05)$. It will comport with results of research of cardiorespiratory system in students of Volga Institute [36].

According to some authors [11] one of the reasons of low physical efficiency of females with body mass deficiency is the insufficient efficiency of cardiovascular system. Decrease in overall performance of cardiovascular system of an organism of females of group " $\mathrm{D}$ " is confirmed by increase in $13,9 \%$ of Robinson Index parameter value in comparison with value of this parameter in females of group " $N$ " (81,6 $\pm 0,52$ and 70,2 $\pm 0,22$ c.u. respectively), $\mathrm{p}<0,05$. Our data will comport with researches concerning the definition of Robinson Index in women of the first mature age with normal body mass index [52].

According to our data, the physical fitness of females with body mass deficiency is much lower in comparison with test results of students with normal body mass. It is confirmed by researches of other authors $[7,11]$. We have found dependence between decrease in level of physical fitness and decrease of female students' body mass. Females of group "D” with gradation of body mass "below average" have lower values of motor tests parameters (situp, trunk flexion), than females of group "N". Females of group "D” with gradation of body mass "low" have rather lower parameters in tests of physical fitness (shuttle run, $20 \mathrm{~m}$ run, 5 min run, sit-up), than females of group "N" $(\mathrm{p}<0,05)$.

The mean score of integral criterion of physical fitness (fig. 2) of females of group " $D$ " with gradation of mass

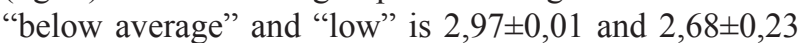
points respectively. It is lower in $13,4 \%$ and in $21,8 \%$ of mean score of students with a normal body mass $(p<0,05)$.

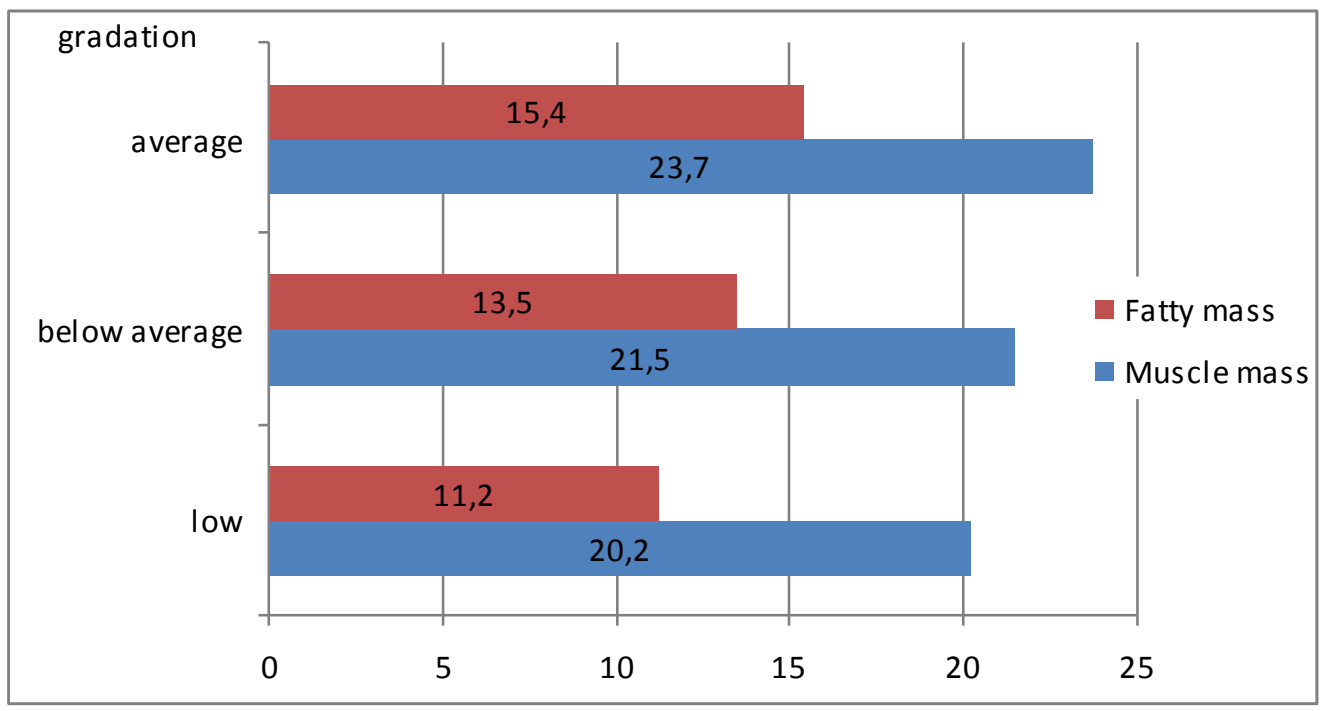

Fig. 1. Muscular and fatty body structure $(\mathrm{kg})$ of females with different gradation of body mass parameter value 


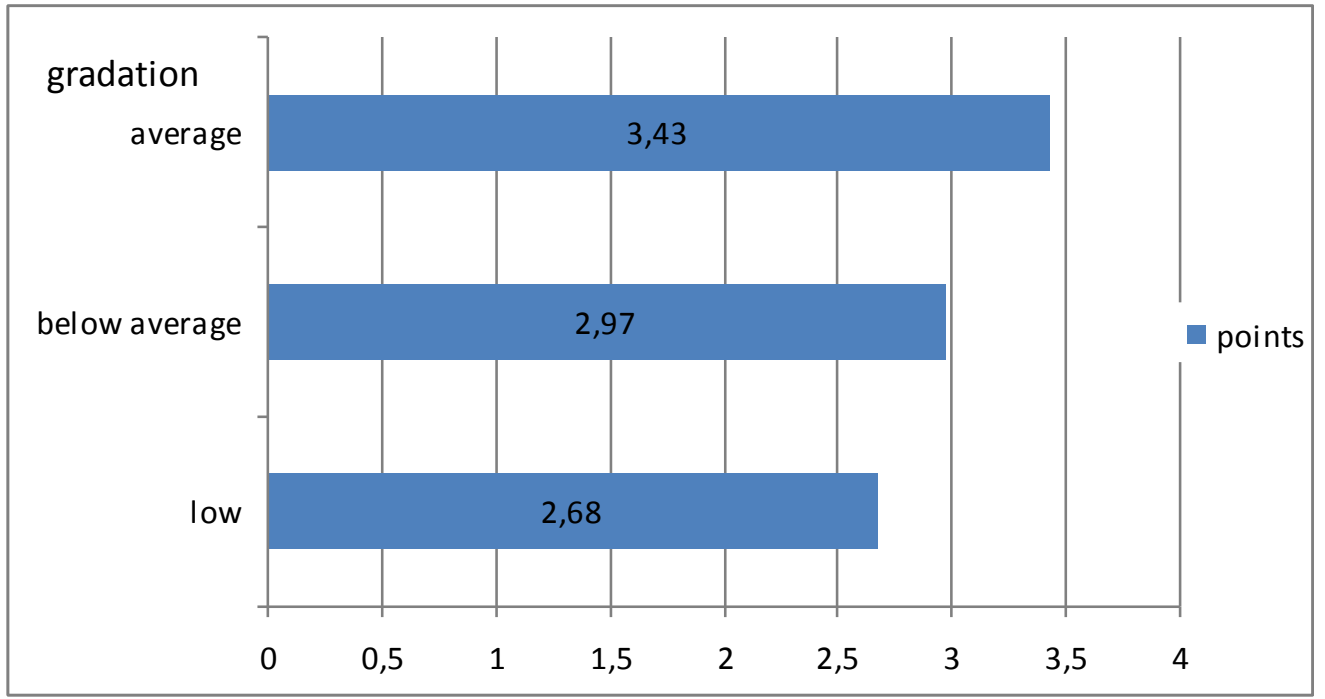

Fig. 2. Integrated criterion of physical fitness level of females with different gradation of body mass parameter value

We presuppose that low characteristics of physical condition of females with body mass deficiency are caused by weak work of myocardium and small content of muscular tissue in body structure. It will comport with the results of other researchers $[31,38]$. The insufficient content of muscular component in females of group " $D$ " leads to decrease in results in motor tests of strength, high-speed and general endurance. These results were lower, than in students with a normal body mass. The muscle mass deficiency doesn't significantly influence on working capacity in the static mode of shoulder girdle muscles [7]. It explains rather high values of parameters in all females with body mass deficiency in the test "hung", in comparison with parameters of students with a normal body mass.

Teachers of physical culture at the universities are recommended to use the individual differentiated approach to the choice of aerobic physical exercises of average intensity for the females with body mass deficiency. It should be used the exercises on the basis of sports and game technologies for the development of speed, strength and dexterity. It adapts the females' cardiovascular system

\section{References}

1. Chaudhuri S, Das B. Body proportions in human physique : A study related to somatometric measurements - some observationsю Anthropology, 1990;28(1):19-26.

2. Hortigüela-Alcalá D, Pérez-Pueyo Á, Moncada-Jiménez J. An analysis of the responsibility of physical education students depending on the teaching methodology received. Journal of Physical Education and Sport, 2015;15(2):202-207. doi:10.7752/jpes.2015.02031

3. Andersen KL, Rutenfranz J, Masironi R, Seliger V. Habitual physical activity and health. Copenhagen: WHO Reg. Publ. Europ.; 1982.

4. Bhviya A, Mostata G. Level and differentials in weight, height and body. J. Biosoc.Sci. 1993;25(1):31-38.

5. Loseva TA, Golubkina NA, Rachkova VP. Physical and mental status of the first year students. Srednee professional'noe obrazovanie, 2011;8:46-47. (in Russian) to physical activities. It also will increase high-speed and general endurance of female students. The further comprehensive study of questions concerning physical fitness of females with body mass deficiency will increase in efficiency of physical training.

\section{Conclusions}

1. 17-21 year-old females with body mass deficiency have rather lower somatometric and functional characteristics of organism (the content of muscle and fatty mass, motor qualities), than in females with a normal body mass $(p<0,05)$. It is determined the less body mass of females, the lower is the level of their physical fitness.

2. The obtained data concerning features and interrelations of the morphofunctional characteristics and motor qualities of females with different body mass allow to correct educational process on physical training with use of integrative pedagogical methods and methods of training.

\section{Conflict of interests}

The author declares that there is no conflict of interests.

6. Orlova SV, Radzinskij VE, Sulejmanova SD, Vasilevskaia LS, Peshkov MV, Sharajkina EP. Body mass index in students: the present state of the problem. Sibirskoe medicinskoe obozrenie, 2014;4:49-56. (in Russian)

7. Egorycheva EV, Musina SV. Study of deviations bodi mass in today's college students. Sovremennye issledovaniia social'nykh problem, 2011;8(4):57-61. doi:10.12731/wsd2016-1-108-123 (in Russian)

8. Mishkova TA, Negasheva MA. The characteristic of physical development of 16-18 year-old male-students of MSU. Moscow; 2002. (in Russian)

9. Aminova OS, Uvarova IuE, Tiatenkova NN. Estimating dietary intake and nutritional status of students. In the World of Scientifi c Discoveries, 2017;9(1):66-77. doi:10.12731/ wsd-2017-1-66-77 (in Russian)

10.Zul'karnaev TR, Salimgaraeva AI, Povargo EA, Zul'karnaeva AT, Agafonov AI. Description of anthropometric indices and 
nutritional status in students in Ufa city. Gigiena i sanitariia. 2012;4:63-65. (in Russian)

11.Solodovnikova IuV, Metina KI, Sakharova OB, Kiku PF, Babko SV. Nutrition and physical development of students (retrospective evaluation). Health. Medical ecology. Science, 2017;1(68):19-23. doi:10.5281/zenodo.345608 (in Russian)

12.Denisova TG, Vasil'eva EN, Gruzinova EN. Etiology and pathogenesis of reproductive system disorders in women with mass deficit (literature review). Zdravookhranenie Chuvashii, 2014;1:10-15. (in Russian)

13.Markova TN, Semakina SM, Rupasova ON, Mikhajlova SA, Tolmacheva AIu, Vladimirova AV. Prevalence of body mass redundancy and obesity in students of medical faculty, doctors and teachers. Zdravookhranenie Chuvashii, 2005;4:33-37. (in Russian)

14.Enikeev BV. Predicting of pregnancy course of and childbirth in women with body mass deficiency. Zdorov'e zhenshchinymateri: voprosy teorii i praktiki, 2006;1:23-26. (in Russian)

15.Karushina LI, Nikitina EA, Muradian EM. Formation of reproductive function in females with a metabolic syndrome. Profilakticheskaia $i$ klinicheskaia medicina. 2010;3(3637):215-216. (in Russian)

16.Lonsdale C, Lester A, Owen KB, White RL, Moyes I, Peralta L, et al. An Internet-supported Physical Activity Intervention Delivered in Secondary Schools Located in Low Socioeconomic Status Communities: Study Protocol for the Activity and Motivation in Physical Education (AMPED) Cluster Randomized Controlled Trial. Bmc Public Health. 2016;16. doi:10.1186/s12889-015-2583-7

17.Mukhanova NV, Savchuk AN. Increase of students motiov activity through motivation necessity to physical training classes. TSPU Bulletin, 2012; 5:171-174. (in Russian)

18. Moy B, Renshaw I, Davids K. The impact of nonlinear pedagogy on physical education teacher education students' intrinsic motivation. Physical Education and Sport Pedagogy. 2016;21(5):517-538. doi:10.1080/17408989.2015.1072506

19.Gavrilik MV. Search for ways of increasing the effectiveness of physical education on students. Zdorov'e dlia vsekh, 2016;2:21-24. (in Russian)

20.Nosko M, Razumeyko N, Iermakov S, Yermakova T. Correction of 6 to 10-year-old schoolchildren postures using muscular-tonic imbalance indicators. Journal of Physical Education and Sport, 2016;16(3):988-999. doi:10.7752/ jpes.2016.03156

21.Olafsdottir AS, Torfadottir JE, Arngrimsson SA. Health Behavior and Metabolic Risk Factors Associated with Normal Weight Obesity in Adolescents. PLOS ONE, 2016;11(8):3440. doi: 10.1371/journal.pone.0161451

22.Haidar A, Carey FR, Ranjit N, Archer N, Hoelscher D. Self-reported use of nutrition labels to make food choices is associated with healthier dietary behaviours in adolescents. Public Health Nutrition. 2017;20(13):2329-2339. doi:10.1017/s1368980017001252

23. Woods AL, Rice AJ, Garvican-Lewis LA, Wallett AM, Lundy B, Rogers MA, et al. The effects of intensified training on resting metabolic rate (RMR), body composition and performance in trained cyclists. Plos One. 2018;13(2). doi:10.1371/journal.pone.0191644

24.Abdullina LB. Formation of healthy lifestyle of students in the conditions of modern higher education institution: practically-focused aspect. Zdorov'esberegaiushchee obrazovanie, 2014;2:78-82. (in Russian)

25.Tolgfors B, Ohman M. The implications of assessment for learning in physical education and health. European Physical Education Review. 2016;22(2):150-166. doi:10.1177/1356336x15595006

26.Lystsova NL Estimation of Health of Students. Fundamental research, 2015;2:1699-1702.

27.Yang CB, Dong MK. A Study of the correlation between teachers' teaching styles and students' participation motivation in the physical education. Journal of Baltic Science Education. 2017;16(2):199-206.

28.Lubysheva LI. Phenomenon of sports culture in aspect of socially pedagogical analysis. Kul'tura fizicheskaia $i$ zdorov'e. 2012;3:5-11. (in Russian)

29.Teixeira TF, Alves RD, Moreira AP, Peluzio M. Main characteristics of metabolically obese normal weight and metabolically healthy obese phenotypes. Nutr Rev. 2015;73(3):175-190. doi:10.1093/nutrit

30.Kolokoltsev M, Iermakov S, Potop V. Creativity project method in academic physical education process. Journal of Physical Education and Sport, 2017;17(4):2659 - 2664. doi:10.7752/jpes.2017.04305

31.Chen H, Sun HC, Dai J, Griffin M. Relationships Among Middle School Students' Expectancy Beliefs, Task Values, and Health-Related Fitness Performance. Journal of Teaching in Physical Education. 2017;36(1):40-49. doi:10.1123/ jtpe.2016-0073

32. Varea V, Underwood M. "You are just an idiot for not doing any physical activity right now': Pre-service Health and Physical Education teachers' constructions of fatness. European Physical Education Review. 2016;22(4):465-478. doi:10.1177/1356336x15617446

33.Bujkova OM, Tristan VG. The influence occupation different type of the aerobics on componental composition of the body student. Obrazovanie, zdravookhranenie, fizicheskaia kul'tura, 2010;19(195):131-134. (in Russian)

34.Aras D, Ewert AW. The effects of eight weeks sport rock climbing training on anxiety. Acta Medica Mediterranea. 2016;32(1):223-230.

35.Iakimovich VS, Egorycheva EV. Correlation of parameters of health and physical readiness of students with deficiency of the body's mass. Uchenye zapiski universiteta imeni P.F. Lesgafta, 2012;5:173-177. (in Russian)

36.Egorycheva EV. Assessment of physical development, functional state and physical readiness of students with deficiency of body weight. Uchenye zapiski universitetata im. P.F.Lesgafta, 2014; 2 (108):66-70. (in Russian)

37.Ulareanu MV, Potop V. Synchronization of biomechanical indicators of clean and jerk style key elements in performance weightlifting. Journal of Physical Education and Sport, 2017;17(Suppl.5):2350 - 2355. doi:10.7752/jpes.2017.s5258

38.Kolokoltsev MM, Buykova OM, Bulnaeva GI. Characteristic features of hemodynamics in students engaged in physical culture. Teoriya i Praktika Fizicheskoy Kultury, 2017-January(3), 8.

39.WMADeclaration of Helsinki - Ethical Principles for Medical Research Involving Human Subjects. 2013. [Internet] 2017 Nov 1 [updated 2018 Jan 1; cited 2017 Nov 8]. Available from: http://www.ub.edu/recerca/Bioetica/doc/Declaracio Helsinki_2013.pdf

40.International Standards for Anthropometric Assessment. 2001. [Internet] 2017 Nov 1 [updated 2018 Jan 1; cited 2017 Nov 8]. Available from: http://www.ceap.br/material/ MAT17032011184632.pdf

41.WHO Global Database on Body Mass Index (BMI). [Internet] 2017 Nov 1 [updated 2018 Jan 1; cited 2017 Nov 8]. Available from: http://knoema.com/WHOGDOBMIMay/ who-global-database-on-body-mass-index-bmi

42.Robinson BF. Relation of heart rate and systolic blood 
pressure to the onset of pain in angina pectoris. Circulation, 1967;35:1073-1083

43.Ikonomi E, Daulle E, Çerra E, Canaj F. Correlation of Anthropometric Indicators to Vital Capacity of Young. International Journal of Science and Research, 2016;5(7):608-614. doi:10.21275/v5i7.ART2016264

44.Nikitina OS, Yevsey AV, Narezkina LP, Pereverzev VA. Normal physiology. Practicum manual for specialty “Stomatology”. Minsk: BSMU; 2016.

45.Matiegka J. The testing of physical efficiency. Am. J. Phys. Anthropol. 1921;4(3):223-230.

46.Maternal anthropometry for prediction of pregnancy outcomes: memorandum from a USAID/WHO/PAHO/ MotherCare meeting. Bull World Health Organ. 1991; 69(5): 609-621.

47.Council of Europe. Testing physical fitness: Eurofit experimental battery-provisional handbook. 1983. [Internet] 2011 June 28 [updated 2018 Jan 1; cited 2017 Nov 8]. Available from: http://www.bitworks-engineering.co.uk/ linked/eurofit $\% 20$ provisional $\% 20$ handbook $\% 20$ leger $\% 20$ beep $\% 20$ test $\% 201983$.pdf.
48.PCFSN. The president's challenge: Physical fitness test. 2011. [Internet] 2011 June 28 [updated 2018 Jan 1; cited 2017 Nov 8]. Available from: https://www.presidentschallenge. org/challenge/physical/index.shtml

49.Lee SY, Gallagher D. Assessment methods in human body composition. Curr. Opin. Clin. Nutr. Metab. Care. 2008;11(5):566-572.

50.Houtkooper LV. Assessment of body composition in youths and relationship to sport. Int. J. Sport. Nutr. 1996;6(2):146164.

51.Dragich OA. Several anthropometric indices of the Ural region agricultural universities students. Vestnik Tiumenskogo universiteta, 2005;5:181-191. (in Russian)

52.Haegele J, Zhu XH, Davis S. Barriers and facilitators of physical education participation for students with disabilities: an exploratory study. International Journal of Inclusive Education. 2018;22(2):130-141. doi:10.1080/13603116.201 7.1362046

\section{Information about the authors:}

Kolokoltsev M.M. (Corresponding author); http://orcid.org/0000-0001-6620-6296; mihm49@mail.ru; Irkutsk National Research Technical University; ul. Lermontov 83, Irkutsk, 664074, Russia.

lermakov S.S.; http://orcid.org/0000-0002-5039-4517; sportart@gmail.com; Department of Tourism and Recreation, Gdansk University of Physical Education and Sport; Kazimierza Górskiego 1, 80-336 Gdańsk, Poland.

Jagiello Marina; http://orcid.org/0000-0001-5591-4537; wjagiello1@wp.pl; Department of Theory of Sport and Human Motority, Gdansk University of Physical Education and Sport; Kazimierza Górskiego 1, 80-336 Gdańsk, Poland.

Cite this article as: Kolokoltsev MM, Iermakov SS, Jagiello M. Physical condition of female students with different level of body mass deficiency. Physical education of students, 2018;22(2):63-69. doi:10.15561/20755279.2018.0202

The electronic version of this article is the complete one and can be found online at: http://www.sportedu.org.ua/index.php/PES/issue/archive

This is an Open Access article distributed under the terms of the Creative Commons Attribution License, which permits unrestricted use, distribution, and reproduction in any medium, provided the original work is properly cited (http://creativecommons.org/licenses/by/4.0/deed.en).

Received: 19.02 .2018

Accepted: 16.03.2018; Published: 27.04.2018 